\title{
DIGITAL TRANSFORMATION MODEL FOR THE DEVELOPMENT OF TOURISM COMPANIES
}

\begin{abstract}
Alex Abelardo Pacheco Pumaleque
Universidad Nacional de Cañete - UNDG, Lima, (Perú).

E-mail: apacheco@undc.edu.pe ORCID: https://orcid.org/0000-0001-9721-0730

Ivan Robles Fernandez

Universidad Tecnológica del Perú - UTP, Lima, (Perú). E-mail: c19255@utp.edu.pe ORCID: https://orcid.org/0000-0002-2510-8312
\end{abstract}

Dany Dorian Isuiza Perez

Universidad Nacional Amazónica de Madre de Dios - UNAMAD, (Perú). E-mail: disuiza@unamad.edu.pe ORCID: https://orcid.org/0000-0002-6132-088X

Marco Antonio Añaños Bedriñana

Universidad Nacional de Cañete - UNDG, Lima, (Perú). E-mail: mananos@undc.edu.pe ORCID: https://orcid.org/0000-0002-4737-4443

\section{Citación sugerida Suggested citation}

Pacheco, A. A., Robles, I., Isuiza, D. D., y Añaños, M. A. (2021). Digital transformation model for the development of tourism companies. 3C Empresa. Investigación y pensamiento crítico. Edición Especial Tourism and University: Backbone of Peruvian Economy, 47-61. https://doi.org/10.17993/3cemp.2021. specialissue 1.47-61 


\section{ABSTRACT}

The way of consuming information and the way we communicate is evolving thanks to advances in technology, the digital transformation breaks new ground in the tourism sector when communicating its services, offers and messages to customers. One of the challenges facing tourism professionals is understanding technological trends to innovate and reinvent their services towards clients. For which we propose a model to adopt the digital transformation in the development of tourist companies. A questionnaire was carried out with 20 managers from the sector with 95\% reliability related to customer management, competition and innovation strategy regarding digital transformation; organizational culture and change management regarding business development. The results show that $45 \%$ indicate that they rarely keep a record with updated customer data. $35 \%$ indicate that they sometimes evaluate business models to anticipate their competition. 35\% rarely use any methodology to develop a business model. This reflects that companies must manage data for later use, invest resources in innovating the business model, and have technological professionals who reinvent business processes.

\section{KEYWORDS}

Digital Transformation, Tourism Companies, Development, Model. 


\section{INTRODUCTION}

Today, companies struggle to survive and execute technology to face the new challenges that the market demands, it is related to digital transformation with devising and transforming culture to make changes in processes, customs and the way of acting of companies and persons; it acts as an indispensable tool for survival in the market (Ametic, 2017). Digital transformation helps companies meet multiple and changing consumer needs, focusing on the importance of data analytics and integrating technology across the business, revamping the way they work to deliver value to customers. This transformation should redirect the entire company towards a digital model that is effective in improving the relationship with the customer (Sánchez, 2019).

Companies are changing the way they do business by creating opportunities to have a competitive advantage, they generate a very important activity since they contribute to the growth of GDP, which allows a series of changes linked to economic aspects, including industrialization processes, communications, commerce and means of transport (Vashi, 2018). The tourism sector has a large and diverse offer, the demand in this sector is potential since there are many clients who are served by mediation systems physically but due to the arrival of technology it was radically transformed (Fundación Orange, 2016).

In tourism, in order to be competitive, the company must have differentiation, reputation and online presence in order to create value for the user and exceed their expectations. Digitization in tourism companies is a long and complicated process, it is related to the cost of implementation, to meet customer expectations, some companies use technology to innovate and provide new products, services and provide information on the business model to their clients, other companies use technology to reinvent themselves by improving their processes and the quality of their products, but there is a high level of ignorance and inappropriate use of new technologies such as cloud computing, big data or business intelligence in the tourism sector, all this added to the high costs of technology implementation, the lack of organization and structure within the company means that they are not at the forefront and available to the customer. 
For this reason, the objective of this research is to propose a model to adopt digital transformation in the development of tourism companies that allows competition in a changing economic environment and prioritizes a roadmap towards digital transformation.

\section{THEORETICAL BASES}

\subsection{DIGITAL TRANSFORMATION}

Companies use new trends in technology such as social networks, mobility, smart devices and improved use of Enterprise Resource Planning ERP to transform processes, customer relationships and the value proposition (Westerman, Bonnet \& McAfee, 2014). In this way, organizations improve their performance and reach through digital technology. It is a great cultural and technological change that all companies must implement to meet the needs of Generation $\mathrm{Z}$ customers. A real digital transformation is obtained when the company becomes aware of the meaning of digital culture applied to all areas of the company (Peña, 2015). This new management model must be adopted by the people and organizational structures.

For Fenwick et al. (2014) all business sectors are obliged to have a change caused by digitization, some will drastically change the business model, leaving the traditional for the modern, which in most cases will be disruptive. A dynamic ecosystem for the organization should be considered, linking the internal and external digital resources of the company as appropriate to promote speed, operational efficiency and achieve a competitive advantage. The advantages of digital transformation make it possible to improve, streamline operations and processes with customers (Sánchez, 2019). Activities such as withdrawing money, depositing money, buying and selling products or services are currently performed virtually, making the economic system quick and easy.

According to a study carried out by Stibo Systems (2016), digitization changes the way of doing business, becoming opportunities to obtain a competitive advantage in this new global digital economy, allowing an organization to be modern, structured and specific that improves the customer experience, increases revenue, fosters a culture of innovation throughout the company, improves internal processes for greater efficiency in the value 
chain and deepens data analysis in all areas of the company. In Figure 1, the barriers to digital transformation are shown.
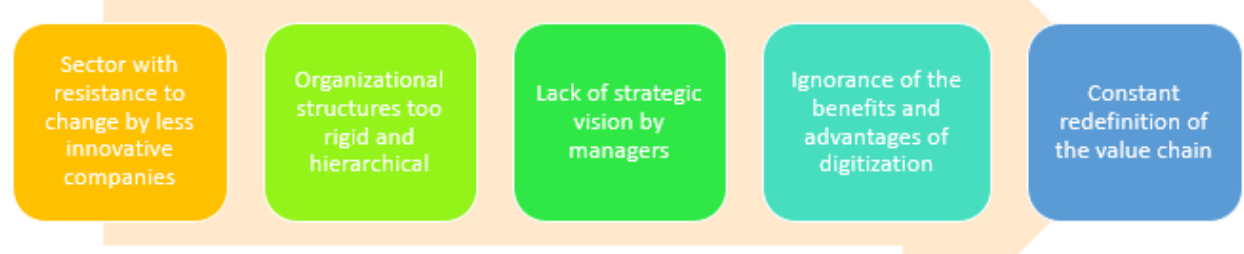

Figure 1. Barriers to digital transformation in companies.

Source: adapted from (Stibo Systems, 2016).

There are information systems for decision-making, from transactional ones that make automatic operational processes saving labor, to strategic ones that provide relevant information that is used in the decision-making process (Bonilla \& Briceño, 2014). They are intended to assist top corporate executives with relevant information and the use of visual resources for easy interpretation. With data analysis, the increase in products and smart systems on the market, companies and factories will have a large number of information.

Analyzing these data will allow finding patterns and interdependencies, studying the processes and finding inefficiencies, including future events (Val, 2016; Pop, 2020). Thanks to data analysis, new opportunities will be found, improving efficiency and discovering services for the client, of which they will have more information. Organizational culture represents a strategic option by interfering with the culture that influences teamwork within the company. The values of each person within a company and the different customs make organizational culture fundamental in all organizations (Knein et al., 2020).

The digital culture influences a change of mentality suggesting changes for the good of the company, with new routine customs of organization and leadership, it is essential for this reason that all companies adopt digitization. The organizational culture intervenes in all the internal relations of the company such as coordination, communication, teamwork, conflict management, authority and autonomy (Runtu et al., 2019). 
The steps to building a strong organizational culture for companies to be successful are: building committed teams, allowing staff to design the culture, hiring qualified staff aligned to the company culture. Customer management is a growing business method, useful for companies to interact with their current and future consumers (Soltani et al., 2018).

The purpose is to analyze historical information on consumers, focusing on retaining customers and increasing sales to improve the customer-company relationship. The management of the customer experience helps us to order the cultural mentality towards the user experience, they are strategies and organizational capacities to maintain loyalty (Holmlund et al., 2020). It is the response of consumers to the interrelationships with a company before, during and after making the purchase that produces a competitive differentiation.

To start with a change management process, companies must practice dialogue and communication with a leader who has an integrating vision for the effective growth of the work of the staff that promotes innovation and creativity for making good decisions in business (Valderrama, 2013). For an organizational change to be carried out with good results, management must keep in mind the global vision of these aspects: elements for change management, factors of change and phases of change, these phases of organizational change are shown in Figure 2 ( Ruiz et al., 2012).

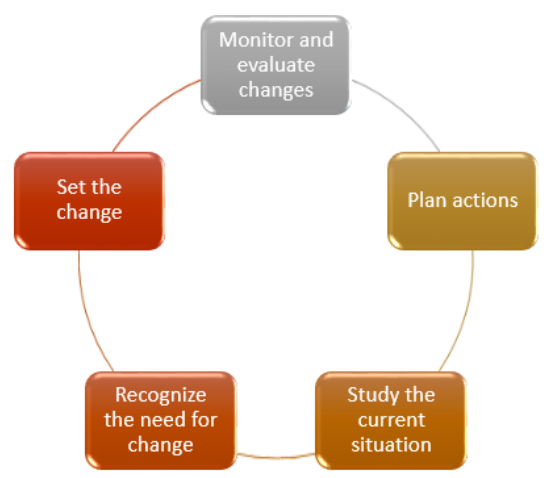

Figure 2. Phases of change.

Source: own elaboration from Ruiz et al. (2012).

The ability of a company to offer products and services but also innovative solutions to meet the expectations and needs of the market is competitiveness (Chiavenato, 2011). Today companies seek to be competitive in order to have an advantage over other organizations seeking the same market and resources, in which consumers demand price, quality, respect 
for ecology and response time. Competition is the situation in which companies are constantly in disputes to sell more products and services in a market (Medina- Quintero et al., 2011), therefore technology positively influences generating competitive advantage, the influence of competition generates opportunities as it increases the intensity of the demand. Companies must choose the innovation strategy they must apply to succeed in the market or only to survive (Kotler et al., 2010).

The most convenient innovation strategy is adapted to the external and internal environment of the company to improve its profitability. Business innovation improves the organization's activities through changes in business models, products, and marketing processes so that the company is more efficient and positions itself in the market. Innovation depends on various aspects such as the tastes and preferences of customers, the globalization of markets and the arrival of new technologies.

\section{METHODOLOGY}

To carry out this research, the quasi-experimental type design applied to 20 MYPES in the tourism sector of Cañete was used. The instrument used was a questionnaire on the digital transformation variable with three indicators: clients, competition, innovation with a total of 15 questions and the business development variable with two indicators: organizational culture, change management with a total of 12 questions. The questionnaire was validated by expert judgment and has a $95 \%$ reliability. The research work was based on four stages: Evaluation of the MYPE, Evaluation Report, proposal and evaluation of results for continuous improvement as shown in Figure 3.

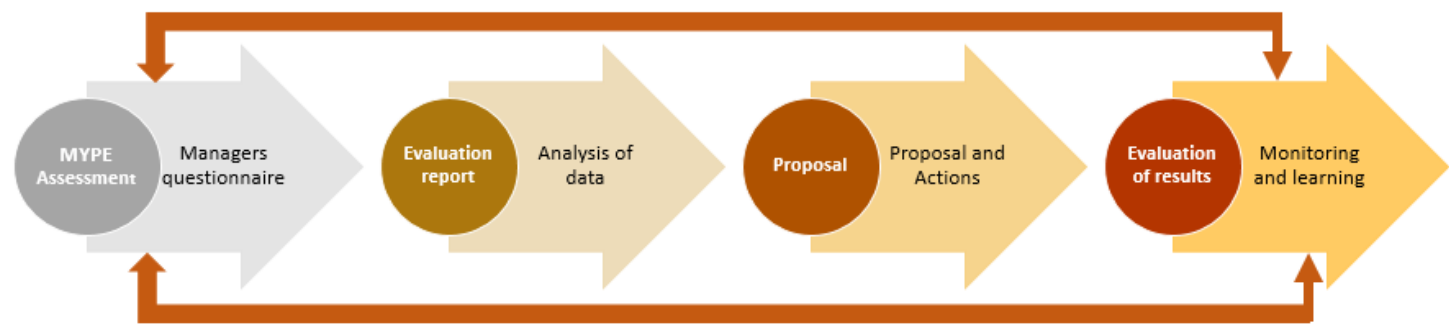

Feedback

Figure 3. Stages of research development.

Source: own elaboration. 


\section{RESULTS}

The questionnaire was carried out to 20 managers of the tourism sector MYPES in Cañete. In Table 1, the customer management dimension of the digital transformation variable indicates that 45\% rarely keep a record with the updated data of their customers, a 25\% sometimes keep track, 15\% never, 10\% often, and 5\% always.

Table 1. Do you keep a record with the updated data of your customers?

\begin{tabular}{|c|c|c|}
\hline Levels & Frequency & Percentage \\
\hline Never & 3 & $15 \%$ \\
\hline Rarely & 9 & $45 \%$ \\
\hline Sometimes & 5 & $25 \%$ \\
\hline Often & 2 & $10 \%$ \\
\hline Always & 1 & $5 \%$ \\
\hline Total & 20 & $100 \%$ \\
\hline
\end{tabular}

Source: Survey of MYPES in the tourism sector.

In Table 2 in the competition dimension of the same variable, 35\% indicate that they sometimes evaluate business models to anticipate their competition, $30 \%$ rarely, 20\% often, $10 \%$ never and $5 \%$ forever.

Table 2. Do you periodically evaluate business models to stay ahead of the competition?

\begin{tabular}{|c|c|c|}
\hline Levels & Frequency & Percentage \\
\hline Never & 2 & $10 \%$ \\
\hline Rarely & 6 & $30 \%$ \\
\hline Sometimes & 7 & $35 \%$ \\
\hline Often & 4 & $20 \%$ \\
\hline Always & 1 & $5 \%$ \\
\hline Total & 20 & $100 \%$ \\
\hline
\end{tabular}

Source: Survey of MYPES in the tourism sector.

In Table 3 in the innovation strategy dimension of the same variable, $35 \%$ rarely make use of any methodology to develop a business model, 30\% sometimes, 15\% always, 10\% a often and another $10 \%$ never. 
Table 3. Do you use any methodology for the development of new business models?

\begin{tabular}{|c|c|c|}
\hline Levels & Frequency & Percentage \\
\hline Never & 2 & $10 \%$ \\
\hline Rarely & 7 & $35 \%$ \\
\hline Sometimes & 6 & $30 \%$ \\
\hline Often & 2 & $10 \%$ \\
\hline Always & 3 & $15 \%$ \\
\hline Total & 20 & $100 \%$ \\
\hline
\end{tabular}

Source: Survey of MYPES in the tourism sector.

In Table 4 in the organizational culture dimension of the business development variable, $40 \%$ express that sometimes the key personnel of the organization have an adequate level of digital knowledge, $35 \%$ rarely, $15 \%$ often and $10 \%$ always.

Table 4. Are ICT used to promote the organizational culture in your company?

\begin{tabular}{|c|c|c|}
\hline Levels & Frequency & Percentage \\
\hline Never & 0 & $0 \%$ \\
\hline Rarely & 7 & $35 \%$ \\
\hline Sometimes & 8 & $40 \%$ \\
\hline Often & 3 & $15 \%$ \\
\hline Always & 2 & $10 \%$ \\
\hline Total & 20 & $100 \%$ \\
\hline
\end{tabular}

Source: Survey of MYPES in the tourism sector.

In Table 5 change management dimension of the business development variable, $40 \%$ indicate that they rarely use technological tools to support change management, $25 \%$ sometimes, $15 \%$ often, $10 \%$ never and $10 \%$ always.

Table 5. Do you use technological tools to support change management?

\begin{tabular}{|c|c|c|}
\hline Levels & Frequency & Percentage \\
\hline Never & 2 & $10 \%$ \\
\hline Rarely & 8 & $40 \%$ \\
\hline Sometimes & 5 & $25 \%$ \\
\hline Often & 3 & $15 \%$ \\
\hline Always & 2 & $10 \%$ \\
\hline Total & 20 & $100 \%$ \\
\hline
\end{tabular}

Source: Survey of MYPES in the tourism sector. 


\section{PROPOSAL}

Based on the results of the survey, the following implementation model for digital transformation is proposed, which helps us to assess the current state of tourism companies, then apply the principles of digital transformation to obtain ideal results.

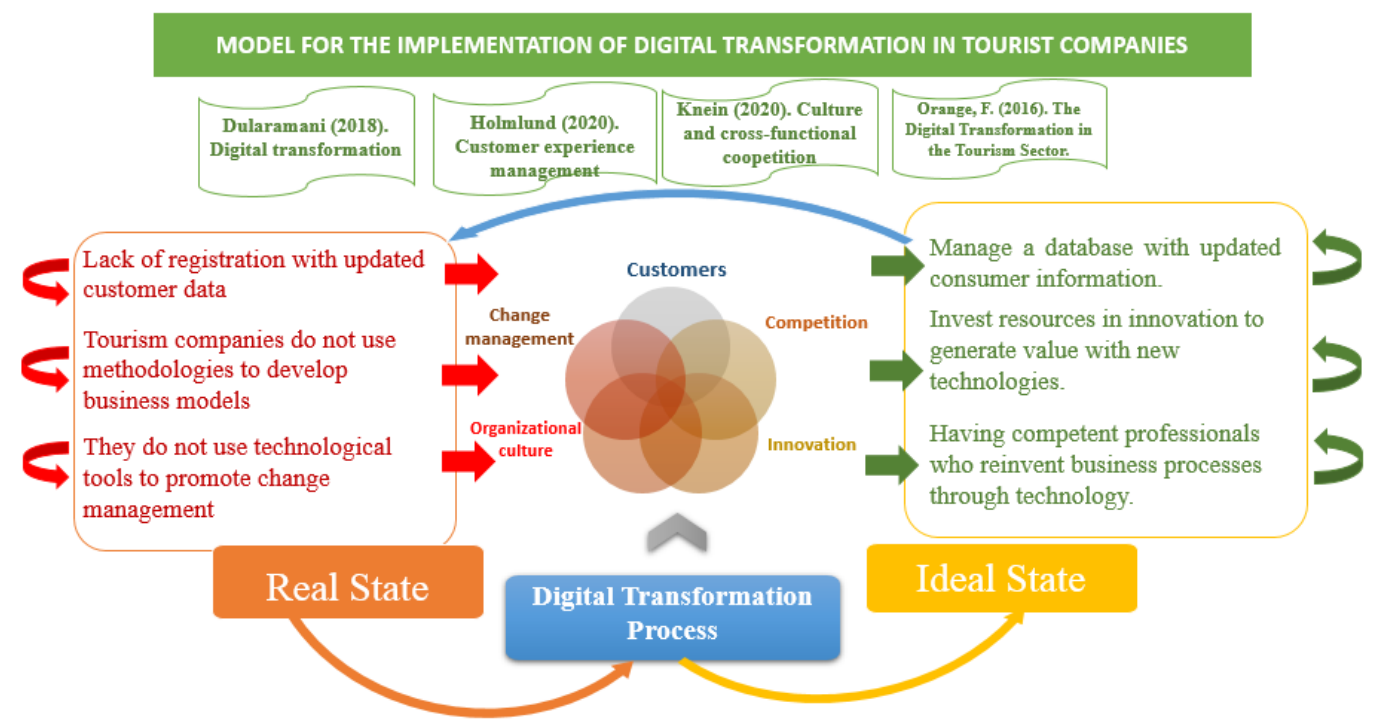

Figure 4. Model for digital transformation.

Source: own elaboration.

\section{CONCLUSIONS}

This research work proposes the application of a digital transformation model for the development of tourist companies based on instruments and techniques carried out in the field work. In Table 1, 45\% of companies in the tourism sector indicate that they rarely keep a record with the updated data of their customers, so they must manage a database that includes demographic and historical information on consumer interests, giving them a higher-level personalization to retain them. This agrees with del Val (2016) and Pop (2020) highlighting the analysis of the data to find patterns and interdependencies, studying the processes and finding inefficiencies to predict future events.

In Table 2,35\% indicates that they sometimes evaluate business models to anticipate the competition. For this reason, tourist MYPES, in order to know what services their clients want, must carry out surveys to analyze the market; make the necessary changes to the 
service through pilot tests to obtain customer feedback; develop strategies through a SWOT analysis to reduce potential problems. This agrees with Chiavenato (2011) and MedinaQuintero et al. (2011) highlighting that competition is the situation in which companies are constantly in dispute to sell more products and services in a market.

In Table 3, 35\% express that they rarely use any methodology for the development of any business model, tourism companies must invest their resources in innovating the business model generating value with new technologies. This agrees with Kotler et al. (2010), expressing that business innovation is an organizational improvement due to changes in the business model, in the organization, in the processes, products and marketing to position itself in the market.

In Table 4, 40\% express that ICTs are sometimes used to promote organizational culture, the results show that Cañete tourism companies must improve the management of information technologies to increase cultural productivity and achieve a new level of improvement. This agrees with Knein et al. (2020) and Runtu et al. (2019), explain that the organizational culture intervenes in all the internal relations of the company such as communication, teamwork, conflict management, authority, autonomy and coordination.

In Table 5, 40\% indicate that they rarely use technological tools to support change management, the data shown shows that companies in the Cañete tourism sector must have professionals with skills and competencies to introduce new technologies that they develop and reinvent the business processes. This agrees with Valderrama (2013) and Ruiz et al. (2012) express that to start a process of change companies must have a dedicated direction to practice dialogue and communication and must also have a leader who has an integrative vision for the growth of the organization through innovation, creativity and use of technology.

\section{ACKNOWLEDGMENT}

Special thanks to the National University of Cañete, the Research Group on Entrepreneurship and Innovation C@ñneteLab, its great professors, valuable students and collaborators for carrying out this scientific article throughout these years of study. Specially to Miss DPMT. 


\section{REFERENCES}

Ametic. (2017). Transformación Digital: Visión y Propuesta de AMETIC. https://www.thinktur. org/media/TD-Vision-y-Propuesta.-AMETIC.pdf

Bonilla, L., \& Briceño, F. A. (2014). Sistemas de Información como apoyo a la toma de decisiones. Prospectiva, 4(1), 53-57. https://www.redalyc.org/ pdf/4962/496251107008.pdf

Ghiavenato, I. (2011). Introducción a la Teoria General de la Administración. https: / / esmirnasite. files.wordpress.com/2017/07/i-admon-chiavenato.pdf

Fenwick, N., Gill, M., Bernoff, J., Ryckewaert, E., \& Wang, N. (2014). The Future Of Business Is Digital: The Powerful Advantages Of Embracing Dynamic Ecosystems Of Value. CMO Professionals. https://www.forrester.com/report/The+Future+Of+Business +Is+Digital/-/E-RES115520\#

Fundación Orange. (2016). La Transformación Digital en el Sector Turístico. http://www. fundacionorange.es/wp-content/uploads/2016/05/eE_La_transformacion_ digital_del_sector_turistico.pdf

Holmlund, M., Van Vaerenbergh, Y., Ciuchita, R., Ravald, A., Sarantopoulos, P., Ordenes, F. V., \& Zaki, M. (2020). Customer experience management in the age of big data analytics: A strategic framework. Journal of Business Research, 116, 356-365. https://doi.org/10.1016/j.jbusres.2020.01.022

Knein, E., Greven, A., Bendig, D., \& Brettel, M. (2020). Culture and cross-functional coopetition: The interplay of organizational and national culture. Fournal of International Management, 26(2), 100731. https://doi.org/10.1016/j.intman.2019.100731

Kotler, P., Berger, R., Bickhoff, N., Kotler, P., Berger, R., \& Bickhoff, N. (2010). Strategy and Strategic Management: A First Basic Understanding. In The Quintessence of Strategic Management (pp. 5-26). Springer Berlin Heidelberg. https://doi. org/10.1007/978-3-642-14544-5_1 
Medina-Quintero, J., Garza, M. I. de la, \& Giménez, K. P. (2011). Competencia empresarial con el uso de la información y la tecnología. Investigación Administrativa, (108). http://www.redalyc.org/articulo.oa?id=45604533900 1

Peña, J. de la. (2015). Todo lo que necesitas saber para adaptarte y sobrevivir a un mundo ya digital. https://www.planetadelibros.com/libros_contenido_extra/31/30114_La_gran_ oportunidad.pdf

Pop, L. D. (2020). Digitalization of the System of Data Analysis and Collection in an Automotive Company. Procedia Manufacturing, 46, 238-243. https://doi. org/10.1016/j.promfg.2020.03.035

Ruiz, J., Ruiz, G., Martínez, I., \& Peláez, J. J. (2012). Modelo para la gestión del cambio organizacional en las PYMES. https://www.upct.es/ economia/PUBLI-INO/ MODELO\%20PARA\%20LA\%20GESTION\%20DEL\%20CAMBIO.pdf

Runtu, T. M., Novieastari, E., \& Handayani, H. (2019). How does organizational culture influence care coordination in hospitals? A systematic review. Enfermeria Clinica, 29, 785-802. https://doi.org/10.1016/j.enfcli.2019.04.119

Sánchez, J. (2019). Transformación e innovación digital. https://www.incipy.com/ebooks/ transformacion-digital.pdf

Soltani, Z., Zareie, B., Milani, F. S., \& Navimipour, N. J. (2018). The impact of the customer relationship management on the organization performance. Fournal of High Technology Management Research, 29(2), 237-246. https://doi.org/10.1016/j. hitech.2018.10.001

Stibo Systems. (2016). Los beneficios y desafios de la transformación digital. http:/ / cdn2. hubspot. net/hubfs/659257/es_site/resources/white-paper/white-paper_digital-disruption_ es.pdf

Val,J. L. del (2016). Industria 4.0: la transformación digital de la industria. Coddiinforme. http:/ / coddii.org/wp-content/uploads/2016/10/Informe-CODDII-Industria-4.0.pdf 
Valderrama, B. (2013). Herramientas para la gestión del cambio. http://www.altacapacidad. com/repositorio/pdf/Herramientas para la gestion del cambio.pdf

Vashi, S. (2018). La transformación digital en el sector turístico: las redes sociales [final degree project]. https://repositorio.comillas.edu/xmlui/handle/11531/18598

Westerman, G., Bonnet, D., \& McAfee, A. (2014). The Nine Elements of Digital Transformation. MITSloan Management Review. https://sloanreview.mit.edu/ article/ the-nine-elements-of-digital-transformation/ 
